\title{
Factors Affecting Student Invest in The Capital Market Through the Investment Gallery of Maarif Hasyim Latif University - Sidoarjo
}

\author{
Adinda Rizky Maulidia, Darno a ${ }^{1}$, Dewi Agustya Ningrum ${ }^{\text {b } 2}$ \\ 1,2 Fakultas Ekonomi dan Bisnis, Universitas Maarif Hasyim Latif, Sidoarjo, Indonesia \\ e-mail: adinda-rizky-maulidia@student.umaha.ac.id, darno@dosen.umaha.ac.id \\ Corresponding Author
}

ARTICLE INFO

\section{Article history}

Received 2020-08-27

Revised 2020-09-10

Accepted 2020-09-17

Keywords

Investment Interest, Investment Knowledge, Investment Capital, Investment Return, Investment Motivation, Investment Gallery

\section{ABSTRACT}

The Indonesia Stock Exchange is intensively conducting a campaign with the theme "Let's Save Stocks" This campaign is intended to change the habits of the Indonesian people from the original savings habit now to become a habit of investing. The research aims to determine the effect of investment knowledge, investment capital, investment return, investment motivation, and investment galleries on the interest of investing in the capital market in S1 Accounting students at Maarif Hasyim Latif University - Sidoarjo.

The method in this research is quantitative. The population in this study were S1 Accounting students in 2015. The samples in this study were 50 students. Data collection was carried out through a questionnaire. Instrument testing in the study used validity and reliability tests. Data analysis techniques using classical assumptions and multiple linear regression analysis.

The results of the study of the influence of investment knowledge, investment capital, investment returns, investment motivation, and investment galleries on the interest of investing in the capital market on Umaha students showed that: (1) the variable of investment knowledge had no significant effect of $0.196>0.05$. (2) investment capital variable does not have a significant effect of $0.462>0.05$. (3) investment return variable has a significant effect of $0.005<0.05$. (4) investment motivation variables have a significant effect of $0.041<0.05$. (5) the investment gallery variable has no significant effect of $0.818>0.05$. (6) the independent variables jointly influence the dependent variables by $50.1 \%$, while the remaining $49.9 \%$ are influenced by other variables not present in this study.

\section{INTRODUCTION}

The capital market is an activity related to securities trading and public offering of various financial instruments such as stocks, bonds (bonds), derivative instruments, resakdana, and other instruments.

The capital market has an important role in the economic development of a country. The existence of a capital market provides benefits for individual investors and business entities that have more funds to invest in companies that have been listed on the Stock Exchange, and entrepreneurs can also develop their business, expand, or increase working capital with additional capital obtained from the investors.

Investment is a way to manage the finances it has for a certain period of time to get returns / profits in the future. There are several types of investment including gold investment, housing, deposits, bonds, stock investment, and so on. Of the several types of investments that have the highest return value at this time is stock investment. IDX research, as of December 29 2017, the average return per year 2006-2017 shows savings of $2.58 \%$, deposits of $7.36 \%$, gold of $7.30 \%$, bonds the state amounted to $8.96 \%$, and shares of $13.13 \%$. 
The Indonesia Stock Exchange as an institution in the capital market is currently aggressively conducting campaigns with the theme "Let's Save Stocks" to invite the public as potential investors in the capital market to buy shares regularly and regularly. This campaign is intended to change the habits of the people in Indonesia from their current saving habits to investing habits. In addition to the campaign with the theme "Let's Save Stocks", the IDX has also provided an Investment Gallery which not only provides news about stock trading activities and other capital market instruments. but also as an activity that provides motivation, outreach and knowledge for people who want to invest in the capital market. Especially among academic students on campus.

Previous research has been conducted on investment motivation and investment knowledge on investment interest in the capital market in FE UNY students [1]. The results of this study indicate that investment motivation and knowledge have an effect on investment interest in the capital market, either partially or simultaneously. The contribution of the influence of the investment motivation variable and knowledge on the investment interest variable was $82.4 \%$, the remaining $17.6 \%$ was from other variables not studied.

Another research conducted looked at the factors that influence student interest in investing in the Islamic capital market. The goal is to provide information to potential investors about investing in the Islamic capital market. The results of the research conducted by the researcher show that the investment benefit variable has a positive influence of 0.000 or $00.0 \%$, the spiritual variable has a positive effect of 0.021 or $02.1 \%$, while the variable that has no positive effect is the minimum investment capital variable in research of 0.880 or $88.0 \%$, the motivation variable is 0.153 or $15.3 \%$, and the return variable is 0.98 or $98 \%$.[2]

Maarif Hasyim Latif University (UMAHA) is one of the universities that already has an Investment Gallery in the Faculty of Economics. Students are excited about the presence of this Investment Gallery at the Faculty of Economics. The enthusiasm of students' interest in the Investment Gallery will provide motivation and benefits and education for the process of establishing the Investment Gallery at Maarif Hasyim Latif University (UMAHA).

Student motivation to invest seems still low, this can be seen when the campus and its administrators

The Investment Gallery held a seminar on the capital market, only a few students attended the seminar. However, this has not been able to measure the level of interest and motivation of students to invest directly in stocks.

This study aims to determine the effect of investment knowledge, investment capital, investment returns, investment motivation, and investment galleries on students' interest in investing in the capital market.

\section{METHOD}

This research was conducted at UMAHA (Maarif Hasyim Latif University) Sidoarjo. This study uses the object of students from the Faculty of Economics and Business (FEB) S1 Accounting Study Program class of 2015. This study aims to determine the factors that influence student interest in investing in the capital market through investment galleries on campus.

This research is a type of quantitative research. The data collection technique in this research is by conducting a survey. The primary data collection instrument used a questionnaire (questionnaire).

\section{Operational Definition of Research Variables}

Variable operational is an action in making the boundaries that will be used in the analysis. As for what will be analyzed is the relationship between the independent variable (free) and the dependent variable (bound). 


\section{Dependent / Bound Variable (Y)}

According to Sugiyono, (2017) the dependent variable is also called the criterion variable, consequent, output. The dependent / dependent variable is the variable that is the result or that is influenced by the existence of the independent variable. The dependent variable used in this study is the student's interest in investing in the capital market.

\section{Independent / Independent Variable (X)}

The independent variable According to Sugiyono, (2017) is also called the stimulus variable, antecedent. The independent variable is the variable that causes or influences the change or growth of the dependent variable. In this study using 5 independent variables (free):

a. Investment knowledge $\left(\mathrm{X}_{1}\right)$

b. Investment capital $\left(\mathrm{X}_{2}\right)$

c. Return on Investment $\left(\mathrm{X}_{3}\right)$

d. Motivation $\left(\mathrm{X}_{4}\right)$

e. Investment Gallery $\left(\mathrm{X}_{5}\right)$

Population and Sample Determination Techniques

According to Sugiyono, (2017) defines population as a general area consisting of objects or subjects that have certain characteristics and qualities that are determined by researchers to study and then draw conclusions. The population used in this study were FEB students (Faculty of Economics and Business), Accounting Study Program, class of 2015, totaling 70 students.

According to Indriantoro, (2009). The sample is the elements obtained from the population as elements of the population. This study uses a portion of the population as a sample of 70 FEB students (Faculty of Economics and Business) Accounting Study Program class of 2015.

This study took a sample size using the Slovin technique and an error rate of 5\%, namely the following formula: (Siregar, 2013)

$$
\mathrm{n}=\frac{\mathrm{N}}{1+\mathrm{Ne} 2} .
$$

Information :

n: sample size

$\mathrm{N}$ : population size

e: estimated error rate

$$
\begin{gathered}
\text { Then }: \mathrm{n}=\frac{70}{1+70(0,05)^{2}} \\
\mathrm{n}=\quad 58.3
\end{gathered}
$$

From the results of the Slovin formula, the total sample size is 58.3 and the nearest rounded is 50 students who will be respondents.

In this study, 30 samples were taken from a total of 50 questionnaires distributed to respondents to test the validity and reliability. If the data test results are reliable and valid, then it is continued to research as many as 50 questionnaires. 


\section{Research Instruments}

1. Questionnaire / Questionnaire

The research instrument is a tool used to collect data needed in research. The instrument in this study was a questionnaire / questionnaire, in which the respondents, namely students of the Faculty of Economics class of 2015, answered several statements on the questionnaire.

2. Likert scale

The scoring in this questionnaire uses a Likert scale measurement, which is a scale containing five levels of preference answers with the following options:
a. Strongly Disagree (STS) 1
b. Disagree (TS) 2
c. Doubt (RR) 3
d. Agree (S) 4
e. Strongly Agree (SS) 5

Method of collecting data

\section{Primary Data}

According to Indriantoro, (2009) primary data is the source of data in research that is obtained directly from the original source. Primary data in this study were obtained from the object of research, namely FEB students (Faculty of Economics and Business) S1 Accounting Study Program class of 2015 through questionnaire data.

\section{Secondary Data}

According to Indriantoro, (2009) Secondary data is the source of data obtained by researchers from intermediary media (obtained by other parties) indirectly. Secondary data in this study are the profile of the Accounting Department at Maarif Hasyim Latif University, and the supporting literature for the research.

Research Instrument Test

A. Validity Test

The validity instrument test is performed to measure whether the measuring instrument is valid or not, in this case a questionnaire. A questionnaire is declared valid if the questions or statements in the questionnaire reveal something that the questionnaire is trying to measure, (Sugiyono, 2017). The questionnaire statement is declared valid if the value of $r$ count $>$ from $r$ table.

\section{B. Reliability Test}

The reliability test shows the extent to which measuring instruments can be relied on or trusted to measure an object to be measured, and to see the consistency of measuring instruments to measure the same symptoms (Sugiyono, 2017). The questionnaire is said to be reliable if it has a Cronbach's $\alpha$ (alpha) value $>$ of 0.6 .

Data analysis technique

1. Classic Assumption Test
a. Normality test
b. Multicollinearity Test
c. Heteroscedasticity Test
d. Autocorrelation Test

\section{Hypothesis Testing}

a. Multiple Linear Regression Analysis 


\section{RESULT AND DISCUSSION}

\section{Research result}

Maarif Hasyim Latif University (UMAHA) is a college located at Jalan Raya Ngelom Megare No.30, Ngelom Kec. Park, Sidoarjo Regency 61257. Maarif Hasyim Latif University (UMAHA) is one of the campuses that already has the Indonesian Stock Exchange GI-IDX Investment Gallery. The Investment Gallery at Maarif Hasyim Latif University has been established since February 27, 2018 in collaboration with PT. Indonesia Stock Exchange and Phintraco Sekuritas. The Investment Gallery is led by the chairman of Bp. Drs. H. Setiawan, MM, Ak, CA. Since the establishment of the Investment Gallery, gallery administrators have socialized it to students by holding several events such as a capital market school which is open to the public, class activation - KSPM (Capital Market Study Group) and various other events.

\section{Respondent General Description}

In this study, 50 respondents from the FEB (Faculty of Economics and Business) study program of S1 Accounting class 2015 used respondents.

Description of respondents based on gender:

1. Male 4 students

2. Female 46 students

\section{Data analysis}

Data processing aims to determine the effect of the variables in the study. Data processing is processed by SPSS software [3]. In this study, the data test technique was carried out using the validity test with Pearson correlation and the reliability test with Cronbach's $\alpha$ (alpha). The test was conducted to determine the accuracy of the data that had been collected from the use of research indicators. While the data analysis technique uses the classical assumption test, namely:

a. normality test

b. multicollinearity test

c. heteroscedasiticity test

d. autocorrelation test

And multiple linear regression analysis to test the hypothesis. This research begins by testing the validity of the questionnaire, namely testing the question items that compose each research variable. The validity test is carried out to determine whether the question item can measure each indicator on each variable under study. Validity and reliability test using data with a total of 30 respondents. To measure the validity, the Pearson product moment correlation is used. If the Pearson product moment correlation value between each question item and the total score produces a significance value less than 5\%, then the statement item is declared valid and vice versa if the significance value is greater than $5 \%$, then the statement item is declared invalid. While the reliability test is used to determine the reliability (consistency) of the instrument (measuring instrument) in the form of a questionnaire. This reliability test was carried out using the Cronbach's alpha technique $\geq 0.60$. Validity and reliability testing was carried out using the SPSS version 17.0 program.

\section{Validity test}

The instrument used in the validity test was the Pearson Correlation. An indicator is said to be valid if the Pearson correlation value is $\geq 0.361$ or the Sig. $\leq 0.05$. The results of validity testing using SPSS Version 17.0 software are as follows: 
Table 1. Validity Test Results

\begin{tabular}{|c|c|c|c|c|c|}
\hline \multirow[b]{2}{*}{ Variable } & \multirow[b]{2}{*}{$\mathbf{X}$} & \multirow[b]{2}{*}{$\mathbf{n}$} & \multicolumn{3}{|c|}{ Validity Test } \\
\hline & & & Pearson Correlation & Sig. & Information \\
\hline \multirow{5}{*}{ Investment Knowledge } & $\mathrm{X} 1.1$ & 30 & 0,833 & 0,000 & Valid \\
\hline & $\mathrm{X} 1.2$ & 30 & 0,687 & 0,000 & Valid \\
\hline & $\mathrm{X} 1.3$ & 30 & 0,765 & 0,000 & Valid \\
\hline & $\mathrm{X} 1.4$ & 30 & 0,749 & 0,000 & Valid \\
\hline & $\mathrm{X} 1.5$ & 30 & 0,833 & 0,000 & Valid \\
\hline \multirow{4}{*}{ Investment Capital } & $\mathrm{X} 2.1$ & 30 & 0,618 & 0,000 & Valid \\
\hline & $\mathrm{X} 2.2$ & 30 & 0,548 & 0,002 & Valid \\
\hline & $\mathrm{X} 2.3$ & 30 & 0,737 & 0,000 & Valid \\
\hline & $\mathrm{X} 2.4$ & 30 & 0,819 & 0,000 & Valid \\
\hline \multirow{5}{*}{ Return on Investment } & X3.1 & 30 & 0,614 & 0,000 & Valid \\
\hline & $\mathrm{X} 3.2$ & 30 & 0,653 & 0,000 & Valid \\
\hline & $\mathrm{X} 3.3$ & 30 & 0,667 & 0,000 & Valid \\
\hline & X3.4 & 30 & 0,471 & 0,009 & Valid \\
\hline & $\mathrm{X} 3.5$ & 30 & 0,698 & 0,000 & Valid \\
\hline \multirow{3}{*}{ Investment Motivation } & $\mathrm{X} 4.1$ & 30 & 0,487 & 0,006 & Valid \\
\hline & $\mathrm{X} 4.2$ & 30 & 0,886 & 0,000 & Valid \\
\hline & $\mathrm{X} 4.3$ & 30 & 0,824 & 0,000 & Valid \\
\hline \multirow{4}{*}{ Investment Gallery } & $\mathrm{X} 5.1$ & 30 & 0,833 & 0,000 & Valid \\
\hline & $\mathrm{X} 5.2$ & 30 & 0,683 & 0,000 & Valid \\
\hline & $\mathrm{X} 5.3$ & 30 & 0,819 & 0,000 & Valid \\
\hline & $\mathrm{X} 5.4$ & 30 & 0,858 & 0,000 & Valid \\
\hline \multirow{6}{*}{ Investment Interests } & Y1.1 & 30 & 0,376 & 0,041 & Valid \\
\hline & Y1.2 & 30 & 0,701 & 0,000 & Valid \\
\hline & Y1.3 & 30 & 0,805 & 0,000 & Valid \\
\hline & Y1.4 & 30 & 0,708 & 0,000 & Valid \\
\hline & Y1.5 & 30 & 0,701 & 0,000 & Valid \\
\hline & Y1.6 & 30 & 0,759 & 0 & Valid \\
\hline
\end{tabular}

Source: Processed Primary Data, 2019

All statement items in the questionnaire have a pearson correlation value $\geq 0.361$ or a Sig value. $\leq 0.05$, it can be concluded that all statement items used to measure the research variables are valid. Therefore, no statement items are deleted or dropped, all statement items can be used in testing the whole model.

Table 2 . Reliability Test Results

\begin{tabular}{|c|c|c|c|}
\hline No & Variable & Alpha Cronbach & Information \\
\hline $\mathbf{1}$ & Investment Knowledge & 0,826 & Reliable \\
\hline $\mathbf{2}$ & Investment Capital & 0,617 & Reliable \\
\hline $\mathbf{3}$ & Return on Investment & 0,601 & Reliable \\
\hline $\mathbf{4}$ & Investment Motivation & 0,618 & Reliable \\
\hline $\mathbf{5}$ & Investment Gallery & 0,810 & Reliable \\
\hline $\mathbf{6}$ & Investment Interests & 0,772 & Reliable \\
\hline
\end{tabular}

Source: Processed Primary Data, 2019 
All statements used in the questionnaire are declared reliable, it can be seen that the Cronbach's alpha value for all research variables has a value greater than 0.60 . So that it can be concluded that the arrangement of the questionnaire statement items for each research variable is declared reliable and can be trusted as a measuring tool that produces consistent answers.

Data Normality Test

Table 3. Normality Test Results

Kolmogorov-Sminorv Sample Test Table

\begin{tabular}{|c|c|}
\hline \multicolumn{2}{|c|}{ One Sample Kolmogorov - Smirnov Test } \\
\hline Asymp. Sig. (2-tailed) & Infomation \\
\hline 0.474 & Normal \\
\hline
\end{tabular}

Source: Processed Primary Data, 2019

Normality test using Kolmogorov Smirnov obtained KSZ (Kolmogorov Smirnov Z) of 0.844 and Asymp. Sig of $0.474>0.05$ or $5 \%$ so that it can be concluded that the data is normally distributed.

Based on the classical assumption test carried out and the output results show that the data meets the requirements for performing multiple linear regression tests.

Multicollinearity Test

Table 4. Multicollinearity Test Results

\begin{tabular}{|c|c|c|c|}
\hline \multicolumn{4}{|c|}{ Coefficiens $^{a}$} \\
\hline \multirow{2}{*}{ Model } & \multicolumn{2}{|c|}{ Collinearity Statistic } & \multirow{2}{*}{ information } \\
\hline & Tollerance & VIF & \\
\hline \multicolumn{4}{|l|}{1 (Constant) } \\
\hline $\mathrm{X}_{1}$ (Investment Knowledge) & 0.593 & 1.685 & \multirow{5}{*}{$\begin{array}{c}\text { Multicol does not } \\
\text { occur } \\
\text { linearity }\end{array}$} \\
\hline $\mathrm{X}_{2}$ (Invesment Capital) & 0.831 & 1.203 & \\
\hline $\mathrm{X}_{3}$ (Return of Investment) & 0.597 & 1.676 & \\
\hline $\mathrm{X}_{4}$ (Investment Motivation) & 0.678 & 1.474 & \\
\hline $\mathrm{X}_{5}$ (Investment Gallery) & 0.551 & 1.814 & \\
\hline
\end{tabular}

Source: Processed Primary Data, 2019

The multicollinearity test results show that all the independent variables have a Tollerance value> 0.10, besides the multicollinearity test results of the VIF value also have the same results, namely that all VIF values of the independent variables have a VIF value $<10$.

Based on the results of the calculation of the multicollinearity test for the Tolerance and VIF values, it can be concluded that there is no multicollinearity between the independent variables (independent variables) in the regression model. 


\section{Heteroscedasticity Test}

Table 5. Heteroscedasticity Test Results

\begin{tabular}{|l|c|c|}
\hline \multicolumn{2}{|c|}{ Coefficiens $^{\mathbf{a}}$} & \multirow{2}{*}{ Information } \\
\hline 1 (Constant) & Sig. & \\
\hline $\mathrm{X}_{1}$ (Investment Knowledge) & 0.063 & \\
\hline $\mathrm{X}_{2}$ (Invesment Capital) & 0.815 & \multirow{3}{*}{$\begin{array}{c}\text { Heteroscedasticity } \\
\text { does not occur }\end{array}$} \\
\hline $\mathrm{X}_{3}$ (Return of Investment) & 0.908 & \\
\hline $\mathrm{X}_{4}$ (Investment Motivation) & 0.100 & \\
\hline $\mathrm{X}_{5}$ (Invesment Gallery) & 0.205 & \\
\cline { 1 - 2 } a. Dependent Variable $:$ Residual & & \\
\hline
\end{tabular}

Source: Processed Primary Data, 2019

The significance value of all variables above is more than 0.05 . Based on these results, it can be concluded that heteroscedasticity does not occur in the regression model in this study.

Autocorrelation Test

Table 6. Autocorrelation Test Results

\begin{tabular}{|c|c|c|}
\hline \multicolumn{2}{|c|}{ Model Summary $^{\mathbf{b}}$} & \multirow{2}{*}{ Information } \\
\hline Model & Durbin - Watson & \\
\hline 1 & 1.941 & There is no autocorrelation \\
\hline \multicolumn{2}{|c|}{ a. Dependent Variable $:$ interest in investment } \\
\hline
\end{tabular}

Source: Processed Primary Data, 2019

The Durbin Watson value is 1,941, the comparison uses a significance value of $5 \%$ the number of samples $(n)=50$ and the number of independent variables $5(k=5)$, then the Durbin Watson table will get the value $(\mathrm{dL}=1.3346)$ and the value $(\mathrm{dU}=1.7708)$. According to the test criteria, it shows that $\mathrm{dU}<\mathrm{d}<(4-\mathrm{dU})=1.7708<1.941<(2.2292)$. Based on these results, it can be concluded that there is no positive or negative autocorrelation.

\section{Hypothesis testing}

The analysis used to test the hypothesis of this study is multiple linear regression analysis. Multiple linear regression analysis was performed to determine the effect of the independent variable (free) on the dependent variable (bound). The following are the results of the calculation of multiple linear regression analysis using SPSS Version 17.0 software.

\section{Output Coefficients}

Table 7. Regression Test Results

\begin{tabular}{|l|c|}
\hline \multicolumn{2}{|c|}{ Coefficiens $^{\mathbf{a}}$} \\
\hline \multicolumn{1}{|c|}{ Model } & B \\
\hline 1 (Constant) & 4.060 \\
\hline $\mathrm{X}_{1}$ (Investment Knowledge) & 0.238 \\
\hline $\mathrm{X}_{2}$ (Investment Capital) & 0.135 \\
\hline $\mathrm{X}_{3}$ (Return of Investment) & 0.505 \\
\hline $\mathrm{X}_{4}$ (Investment Motivation) & 0.335 \\
\hline $\mathrm{X}_{5}$ (Invesment Gallery) & -0.054 \\
\hline a. Dependent Variable : Investment Interests \\
\hline
\end{tabular}

Source: Processed Primary Data, 2019 
Based on the results of the regression test above, the multiple linear regression equation in this study is as follows:

$$
\text { interest in investment }=4.060+0.238 X_{1}+0.135 X_{2}+0.505 X_{3}+0.335 X_{4}-0.054 X_{5}
$$

The explanation of the regression equation above is as follows:

1. A constant of 4.060 means that if the independent variable $X_{1}$ (Investment Knowledge), $X_{2}$ (Investment Capital), $\mathrm{X}_{3}$ (Investment Return), $\mathrm{X}_{4}$ (Investment Motivation), and $\mathrm{X}_{5}$ (Investment Gallery) $=0$, then the dependent variable (Investment Interest) is equal to 4,060.

2. The variable $\mathrm{X}_{1}$ (Investment Knowledge) has a value of 0.238 , meaning that every time there is an increase in $\mathrm{X}_{1}$ (Investment Knowledge) by $1 \%$, the Investment Interest will increase by $23.8 \%$. It is assumed that other variables are constant.

3. The variable $\mathrm{X}_{2}$ (Investment Capital) has a value of 0.135 , meaning that every time there is an increase in $\mathrm{X}_{2}$ (Investment Capital) by $1 \%$, the Investment Interest will increase by $13.5 \%$. It is assumed that other variables are constant.

4. The variable $\mathrm{X}_{3}$ (Return on Investment) has a value of 0.505 , which means that every time there is an increase in $\mathrm{X}_{3}$ (Return on Investment) of 1\%, the Investment Interest will increase by $50.5 \%$. It is assumed that other variables are constant.

5. The variable $\mathrm{X}_{4}$ (Investment Motivation) has a value of 0.335 which means that every time there is an increase in $\mathrm{X}_{4}$ (Investment Motivation) of 1\%, the Investment Interest will increase by $33.5 \%$. It is assumed that other variables are constant.

6. The variable $\mathrm{X}_{5}$ (Investment Gallery) has a value of -0.054 which means that every time there is an increase in $\mathrm{X}_{5}$ (Investment Gallery) by $1 \%$, investment interest will decrease by $5.4 \%$. It is assumed that other variables are constant.

Partial Test ( $\mathrm{t}$ test)

Table 8. Partial Test Result ( $\mathrm{t}$ test)

\begin{tabular}{|l|c|c|}
\hline \multicolumn{1}{|c|}{ Model } & \multirow{2}{*}{ 'oefficiens ${ }^{\mathbf{a}}$} & Information \\
\hline 1 (Constant) & 0.284 & not significant \\
\hline $\mathrm{X}_{1}$ (Investment Knowledge) & 0.196 & not significant \\
\hline $\mathrm{X}_{2}$ (Investment Capital) & 0.462 & Significant \\
\hline $\mathrm{X}_{3}$ (Return of Investment) & 0.005 & Significant \\
\hline $\mathrm{X}_{4}$ (Investment Motivation) & 0.041 & not significant \\
\hline $\mathrm{X}_{5}$ (Investment Gallery) & 0.818 & \\
\hline a. Dependent Variable $:$ Investment Interests & & \\
\hline
\end{tabular}

Source: Processed Primary Data, 2019

From the results of the $t$ test, it was obtained 2 variables that had a significant effect on student interest in investing in the capital market through the investment gallery at UMAHA, namely investment return and investment motivation, while the variables of investment knowledge, investment capital, and investment gallery had no significant effect because they had a sig value. $>0.05$.

Simultaneous hypothesis testing $(\mathrm{F}$ test)

Table 9 Simultaneous Test Results (Test F)

\begin{tabular}{|l|c|c|c|}
\hline \multicolumn{2}{|c|}{ ANOVA $^{\mathbf{b}}$} & \multirow{2}{*}{ Information } \\
\hline \multicolumn{1}{|c|}{ Model } & F & Sig. & significant \\
\hline 1 Regression & 8.832 & $0.000^{\mathrm{a}}$ & \\
\hline Residual & & & \\
\hline Total & & \\
\hline a. Predictors : (Constant)X1, X2, X3, X4, X5 & \\
\hline b. Dependent Variable : interest in investment & \\
\hline
\end{tabular}

Source: Processed Primary Data, 2019 
The results of the simultaneous $F$ test in the table above obtained Fcount of 8.832 with a sig of 0.000 . Sig value. is smaller than the probability value 0.05 or $0.00<0.05$ so that Ha is accepted and means $\mathrm{X}_{1}$ (Investment Knowledge), $\mathrm{X}_{2}$ (Investment Capital), $\mathrm{X}_{3}$ (Investment Return), $\mathrm{X}_{4}$ (Investment Motivation), and $\mathrm{X}_{5}$ (Investment Gallery) together ( simultaneous) has a significant effect on investment interest.

Determination Coefficient Test $\left(\mathrm{R}^{2}\right)$

Table 10 Test Results Coefficient of Determination $\left(\mathrm{R}^{2}\right)$

\begin{tabular}{|c|c|}
\hline \multicolumn{2}{|c|}{ Model Summary $^{\mathbf{b}}$} \\
\hline Model & \multicolumn{2}{c|}{ R Square } \\
\hline 1 & 0.501 \\
\hline a. Predictors : (Constant)X1, X2, X3, X4, X5 \\
\hline b. Dependent Variable $:$ interest in investment \\
\hline
\end{tabular}

Source: Processed Primary Data, 2019

The results of the summary table above have an R Square value of 0.501 , this means $50.1 \%$, so the conclusion is $\mathrm{X}_{1}$ (Investment Knowledge), $\mathrm{X}_{2}$ (Investment Capital), $\mathrm{X}_{3}$ (Investment Return), $\mathrm{X}_{4}$ (Investment Motivation), and $\mathrm{X}_{5}$ (Investment Gallery) collectively, it has an effect of $50.1 \%$ on Investment Interest, while the remaining $49.9 \%$ is influenced by other variables that are not in this study.

\section{Discussion}

\section{Investment Knowledge $\mathrm{X}_{1}$}

The results of the research that have been conducted show that the regression coefficient $\mathrm{X}_{1}$ is 0.238 , meaning that every time there is an increase in $\mathrm{x} 1$ (investment knowledge) of $1 \%$, investment interest will increase by $23.8 \%$. The significance value is $0.196>\alpha=0.05$, it means that investment knowledge $\left(\mathrm{X}_{1}\right)$ has no significant effect on investment interest. Based on these results, the conclusion is that $\mathrm{H}_{1}$, namely investment knowledge has a significant effect on student interest in investing in the capital market is rejected.

\section{Investment Capital $\mathrm{X}_{2}$}

The results of the research that have been done show the regression coefficient $\mathrm{X}_{2}$ of 0.135 , meaning that every time there is an increase in $\mathrm{X}_{2}$ (investment capital) by $1 \%$, investment interest will increase by $13.5 \%$. The significance value is 0.462 . $>\alpha=0.05$. It means that investment capital $\left(\mathrm{X}_{2}\right)$ has no significant effect on investment interest. Based on these results, the conclusion is that $\mathrm{H}_{2}$, namely investment capital has a significant effect on student interest in investing in the capital market is rejected.

3. Return on investment $\mathrm{X}_{3}$

The results of the research that have been conducted show that the regression coefficient $\mathrm{X}_{3}$ is 0.505 , meaning that every $1 \%$ increase in $\mathrm{X}_{3}$ (investment return) will increase interest in investment by $50.5 \%$. The significance value is $0.005 .<\alpha=0.05$. It means that investment return $\left(\mathrm{X}_{3}\right)$ has a significant effect on investment interest. Based on these results, the conclusion is $\mathrm{H}_{3}$, namely investment return has a significant effect on student interest in investing in the capital market is accepted.

4. Investment Motivation $\mathrm{X}_{4}$

The results of the research that have been conducted show that the regression coefficient $\mathrm{X}_{4}$ is 0.335 , meaning that every $1 \%$ increase in $\mathrm{X}_{4}$ (investment motivation) will increase interest in investment by $33.5 \%$. The significance value is $0.041 .<\alpha=0.05$. It means that investment motivation $\left(\mathrm{X}_{4}\right)$ has a significant effect on investment interest. Based on these results, the 
conclusion is that $\mathrm{H}_{4}$, namely investment motivation has a significant effect on students' interest in investing in the capital market is accepted.

5. Investment Gallery $\mathrm{X}_{5}$

The results of the research that have been conducted show the regression coefficient $\mathrm{X}_{5}$ of -0.054 , meaning that every $1 \%$ increase in $\mathrm{X}_{5}$ (gallery investment), investment interest will decrease by $5.4 \%$. The significance value is $0.818>\alpha=0.05$. This means that the investment gallery $\left(\mathrm{X}_{5}\right)$ has no significant effect on investment interest. Based on these results, the conclusion is that $\mathrm{H}_{5}$, namely the investment gallery has a significant effect on student interest in investing in the capital market is rejected.

6. The effect of investment knowledge, investment capital, investment returns, investment motivation, and investment galleries on students' interest in investing in the capital market.

From the previous results it can be seen that the variables of investment knowledge, investment capital, investment returns, investment motivation and investment galleries are able to influence student investment interest in investing in the capital market.

From the $\mathrm{F}$ test table, it is obtained that the Fcount is 8,832 with a sig of 0,000 . The sig value is smaller than the probability value 0.05 or $0.00<0.05$, then $\mathrm{Ha}$ is accepted and means $\mathrm{X} 1$ (Investment Knowledge), X2 (Investment Capital), X3 (Investment Return), X4 (Investment Motivation), and X5 (Investment Gallery) together - same (simultaneous) effect on Investment Interest.

\section{CONCLUSIONS AND RECOMMENDATIONS}

\section{Conclusion}

1. The knowledge investment variable $\left(\mathrm{X}_{1}\right)$ has no significant effect on the interest of accounting students class 2015 at Maarif Hasyim Latif University Sidoarjo to invest in the capital market. This is because previous students have obtained a portfolio theory course in semester 5 , students are more concerned with the risks that exist in the capital market.

2. The investment capital variable $\left(\mathrm{X}_{2}\right)$ does not have a significant effect on the interest of accounting students class 2015 at Maarif Hasyim Latif Sidoarjo University to invest in the capital market. This is because most students have worked while studying so that investment capital is no longer a problem for investing. It's just that they don't have much time to practice investing directly in the capital market or to learn more about investing.

3. The variable return on investment $\left(\mathrm{X}_{3}\right)$ has a significant effect on the interest of accounting students in batch 2015 at Maarif Hasyim Latif Sidoarjo University to invest in the capital market. One of the things that makes students interested in investing is because the level of return on investment in the capital market is greater than just saving in a bank. The benefits of investing can be obtained from capital gains and dividends given by the company. This is a factor for students' interest in investing in the capital market. The investment motivation variable $\left(\mathrm{X}_{4}\right)$ has a significant effect on the interest of accounting students class of 2015 at Maarif Hasyim Latif Sidoarjo University to invest in the capital market. The existence of a colleague or the closest person to the student who has made an investment and has benefited from the investment makes students motivated to do the same with his partner, namely investing in the capital market.

4. The investment gallery variable $\left(\mathrm{X}_{5}\right)$ has no significant effect on the interest of accounting students class 2015 at Maarif Hasyim Latif Sidoarjo University to invest in the capital market. This may occur because the establishment of the Investment Gallery at Maarif Hasyim Latif University Sidoarjo can be said to be still new, so some students have not. get to know what the Investment Gallery is. 
5. The variables of investment knowledge, investment capital, investment return, investment motivation and investment gallery are able to influence student investment interest in investing in the capital market.

Suggestion

1. Higher education institutions (campuses) are expected to provide provisions not only in the form of theory, but in continuous practice so that the hope is that students are really required to be directly involved in investment activities in the capital market.

2. Providing provisions in improving investment skills through various platforms such as seminars, capital market schools, KSPM (Capital Market Study Group) and materials received in courses.

3. Shaping the character of investors in each student, forming a mentality of self-confidence and the courage to take risks that will be faced.

4. Providing a forum for students to share and learn about investing in the capital market.

5. Introducing the Investment Gallery in every event in higher education institutions and in the community around the university environment so that more students and the general public who previously used to save have turned into investing.

\section{REFERENCES}

Hermuningsih, Sri. 2013. Introduction to the Indonesian Capital Market. Bandung: Alfabeta.

Indriantoro, N., \& Bambang, S. 2009. Business Research Methodology for Accounting \& Management (First,). Yogyakarta: BPFE.

Kusmawati. 2011. The Influence of Motivation on Interest in Investing in the Capital Market with an Understanding of Investment and Age as Moderate Variables. Journal of Economics and Accounting Information (Jenius), Vol. 1 No. 2, May 2011, P: ISSN: 2302-514X. e: ISSN: 2303-1018.

Karima, L. (2018). Analisis Faktor-Faktor yang Mempengaruhi Minat Mahasiswa untuk Melakukan Investasi di Pasar Modal Syariah (Studi Kasus Mahasiswa Fakultas Ekonomi Universitas Islam Indonesia). E-Print:Dspace Uii. https://dspace.uii.ac.id/handle/123456789/8150

Pajar, R. C., \& Pustikaningsih, A. (2017). Pengaruh Motivasi Investasi Dan Pengetahuan Investasi Terhadap Minat Investasi di Pasar Modal Pada Mahasiswa FE UNY. Profita Kajian Ilmu Akuntansi, 5(1). http://journal.student.uny.ac.id/ojs/index.php/profita/article/view/9628

Siregar, S. 2013. Parametic statistics for quantitative research. Jakarta: Earth Literacy.

Sugiyono. 2017. Quantitative, Qualitative, and R \& D Research Methods. Bandung: Alfabeta, CV.

PT. Indonesia stock exchange. 2019. Downloaded on March 3, 2019 from https://www.idx.co.id/

Internet Sources:

Maarif Hasyim Latif University. 2019. Downloaded on March 3, 2019 from https://www.umaha.ac.id/selayang-pandang/

Let's Save Stocks. 2019. Downloaded on March 3, 2019 from http://yuknabungsaham.idx.co.id/. 